\title{
The Willingness to Pay for Cider Products: Results of a Survey on Habits and Consumption Behavior
}

\author{
Eric Le Fur ${ }^{1}$, J. François Outreville ${ }^{2}$ \\ ${ }^{1}$ Economics, INSEEC Bordeaux, ${ }^{2}$ Wine and Spirits Business, Burgundy School of Business \\ Keywords: consumption behavior, survey, cider, willingness to pay \\ https://doi.org/10.26813/001c.28199
}

\section{Wine Business Journal}

Vol. 5, Issue 1, 2022

\section{Purpose}

The objective of the paper is to investigate the impact of habits and consumption behavior on the willingness to pay (WTP) for cider by surveying young consumers.

\begin{abstract}
Method
The analysis is based on a questionnaire distributed to a group of 433 French business students from December 2017 to January 2018. Specifically, the questionnaire is designed to test whether young consumers would pay a premium price or not for quality ciders with respect to a traditional sweet cider with similar characteristics. We are modelling the premium that consumers are willing to pay for an organic cider, a farmer cider and rosé cider. To accommodate the feature of a significant proportion of zero or negative premiums in dependent variables, the Heckman two-stage estimation procedure is performed.
\end{abstract}

\section{Results}

Results show that the young generation consider cider as a cheap, festive and non-organic beverage and is willing to pay a premium for quality ciders like specifically rosé and farmer ciders.

\section{Conclusion}

The results from this research have useful implications not only for the cider market but also in the understanding of the characteristics of competitive beverages that young consumers may prefer and value.

\section{Introduction}

Cider production is popular around the world in temperate regions where apple trees grow. Evidence along the banks of the Nile River can be found dating back to about 1300 B.C., but the historical development of cider production is less clear (Watson, 2003). Today, the bulk of production of cider occurs in Europe where the term cider refers strictly to fermented products. Within Europe, the main cider-producing countries are England, Spain, France, Germany, and Ireland, while smaller amounts are produced in Finland, Poland, Austria, and Switzerland (AICV, 2018). The consumption of cider is also mainly European with the old continent accounting for about 70 percent of worldwide cider consumption. After a period of decreasing consumption, the cider market has increased significantly since 2013 (AICV, 2018). A comparative analysis of the markets of still wine, beer, and cider reveals that the cider market will register the highest growth in the next years (IWSR, 2019). Diversified and high-quality products and innovations such as cider rosé, ice cider, and flavored ciders may explain this renewed interest in cider by young consumers (Cloutier \& Détolle, 2017; Fabien-Ouellet \& Conner, 2018). Also, Generation Z consumers (born after 1996) drink less alcohol in general according to a 2018 survey by Berenberg Research (Pepper, 2018) and focus on lower alcoholic beverages, new ready-to-drink, or pre-mixed beverages (Craigs et al., 2011; Foster et al., 2003). ${ }^{1}$

\section{Conceptual Framework}

Cider, like wine, is an experience good that possesses a few characteristics that differentiate it from other beverages. However, unlike the wine market (Charters \& Pettigrew, 2008; Fogarty, 2010), there is little information about 
consumer preferences for cider (Sousa, 2014). There are two common approaches to estimate consumer valuation for product characteristics. First, hedonic price analysis correlates the price of a differentiated product to its characteristics. The technique is commonly used in the alcoholic sector and notably in the wine industry (Cardebat \& Figuet, 2004; Lecocq \& Visser, 2006; Oczkowski \& Doucouliagos, 2015; see J.-F. Outreville \& Le Fur, 2020 for a survey) as well as in a non-alcoholic sector such as water (Capehart, 2015). J. F. Outreville \& Le Fur (2020)apply this analysis to examine the determinants of the price of cider and emphasize the importance of high-quality products and geographical factors related to the region of origin.

Second, the willingness to pay (WTP) estimation is based on the maximum price at which a consumer will definitely buy one unit of a product. This corresponds to the standard economic view of consumer reservation price (RP). According to Bearden et al. (1992), WTP and RP are correlated and WTP can be considered as the upper limit for RP (Kalyanaram \& Little, 1994). Although Adaval \& Monroe (2002) raise the question of stability because the measurement is only valid within a given moment in time and a given environment, the methodology is commonly used in the wine sector (Brugarolas Mollá-Bauzá et al., 2005; Holmquist et al., 2011; Lecat et al., 2016; Nelson Barber, 2009; SellersRubio \& Nicolau-Gonzalbez, 2016; Yang et al., 2009).

In the cider market, Didier et al. (2012) distinguish four types of consumption: basic, traditional, pleasure, and festive. They show that consumers differ in their preferences for specific characteristics of ciders, but are not able to value individual ciders or characteristics of these ciders. Tozer et al. (2015) identify the characteristics of craft cider that consumers prefer and value and develop a framework for an objective analysis of cider and the determination of consumer WTP utilizing this framework. Variables that affect the WTP for cider include age, whether the participant is a cider or beer drinker, and the sensory attributes related to taste, flavor, and aroma.

Purchase and consumption behaviors in daily life often are repetitive and performed in customary places, leading consumers to develop habits (Ji \& Wood, 2007). When habits have formed, they impact future consumption behavior (Pollak, 1970, 1976). N. Barber et al. (2006) and Thach \& Olsen (2006) were among the first to study the perceptions and attitudes of young adults regarding wine consumption. Young adults consider wine as a good beverage to drink with food or for social occasions with family and friends (Olsen et al., 2007). Young adults are also more likely to consume alcoholic beverages outside and prefer beer and ready-todrink beverages. To our knowledge, no study applies the WTP approach to understand whether the habits and customs of young consumers impact their willingness to pay for a bottle of cider.

The aim of our study is to identify the perceptions, attitudes, and behavior of young adults towards cider consumption. As Generation $\mathrm{Z}$ enters the workforce and their purchasing power increases, companies cannot afford to act within conventional assumptions or existing generational frameworks. To target this young generation, our survey is conducted with students using a questionnaire similar to those used in previous studies (Lecat et al., 2016). The questionnaire requires a choice (positive or negative) according to attitude, customs, and habits and asks students how much they are willing to pay for one specific bottle of cider. Four types of ciders are proposed. The answer is a statement of preference for which there is no right or wrong answer. The questionnaire was distributed from December 2017 to January 2018 at INSEEC Bordeaux Business School in France. The population is composed exclusively of French business students.

The objectives of this research are to identify the characteristics of cider that consumers prefer and value and to develop a framework for the analysis of the determination of consumer WTP. Our hypothesis is that WTP is impacted by habits and past consumption behavior. The results from this research can also be useful to craft cider makers in the understanding of cider characteristics that young consumers prefer and value.

Our results suggest that: 1) students consider cider as a cheap, festive, and non-organic beverage. Cider is associated with special events like an epiphany. Even though cider is considered as an alcoholic beverage and often compared with beer; it may also be associated with nonalcoholic beverages like soda; 2) students are willing to pay almost 50 percent more for specific quality ciders like rosé, farmer and organic ciders and WTP is dependent on gender, customs, and habits.

\section{Questionnaire}

The focus of the study is students' WTP for a bottle of cider. Cider can be judged in terms of three qualities: its acidity, tannins, and sugar level (the higher the sugar level, the lower the alcohol level). Sweet cider (less than 3 percent volume), which goes well with pancakes or desserts, develops a very fruity flavor. Other ciders, dry or hard ciders (4 percent volume or higher), are slightly more bitter or more sparkling. In the questionnaire, the answers are hypothesized to be independent of the qualities of ciders and purchase location but are supposed to reflect the taste preferences of consumers. ${ }^{2}$

There is another possible classification of varieties of cider. A cider that is labeled "farm cider" is grown and processed on the same farm using traditional techniques. If the cider is "organic", it is a bioproduct with the letters $\mathrm{AB}$ on the label. Most recently, the "rosé" trend has found its way to hard cider using either red-flesh apples to give ciders that distinctive millennial-pink or adding berries to the beverage. Study participants must indicate how much they are willing to pay for a bottle of cider belonging to this classification without reference to any brand. 
Choice-based surveys assess purchase decisions and behavior using "revealed choice modeling” (N. A. Barber \& Taylor, 2013). In these studies, although the utilities of consumers are not exactly the same, they are assumed to be similar in size and sign, indicating that choice can be used to recover specific values of purchase decisions (Lockshin \& Hall, 2003). The framework of the analysis is static, i.e., the subject cannot review his or her decision in a subsequent assessment.

The questionnaire is presented in Appendix 1. It includes 14 questions divided into three components. The first part defines habits, customs, and preferences about cider. Since Pollak $(1970,1976)$ we know that current preferences are influenced by past consumption and consequently that habit formation influences the current demand for a good.

In the second part of the questionnaire, each participant is asked to indicate the amount they are willing to pay for four specific cider products. These questions do not require a choice between several answers but rather a monetary amount for which there is no right or wrong answer per se.

Finally, the last set of questions capture personal details about each participant. Purchase decisions are influenced by consumer personality traits (Orth \& Kahle, 2008). A 5-point Likert scale is used to ask participants how they perceive themselves compared to the group for two types of traits of character/personality (Orth \& Malkewitz, 2008). The questions are asked at the end of the questionnaire after the responses to questions related to WTP. It is possible that if questions were located at the beginning of the questionnaire, this would influence the following answers. It was therefore decided to locate the questions at the end of the questionnaire.

The reference group for the survey is the student population in a French business school. According to a recent publication, about half of French students drink alcohol at least once per week (FAGE, 2014). Among these students, 2 percent have an excessive daily consumption, but this result remains lower than the general consumption of the 18-25 years' cohort (Arvers, 2011; Richard et al., 2013). These studies also indicate that male students are more addicted than female students. If 7 percent of respondents declare they do not drink alcohol, 77 percent of respondents consume alcohol to go out, be social, and party, and 23 percent of respondents declare to consume because their friends also consume (Rouillier et al., 2004).

The targeted population is the student population with the hypothesis that most of the subjects have some knowledge of the cider market and that the situation presented in the questionnaire is known to them. This approach aligns with the idea of familiarity with a product discussed by Alba \& Hutchinson (1987) and the role of prior experience discussed by Brucks (1985). However, this is not a necessary condition for the study. ${ }^{3}$

\section{Methodology}

The survey was conducted in December 2017 and January 2018 at INSEEC Bordeaux Business School in France. The population is only composed of French business students between 19 and 25 years old. 37 percent of the students were in the last year of their Bachelor's degree, 30 percent in the first year of their Master's degree, and 33 percent in the second year of their Master's degree. Questionnaires were distributed in paper format in several batches before the beginning of each class with an explanation of the purpose and content of the questionnaire. In order to avoid possible linguistic biases, the distribution was done in French, i.e., in the native language of the respondents, thus ensuring a perfect understanding of the content. In addition, questionnaires with biases such as multiple responses instead of one, outlier answers, or excessive omissions, were excluded from the study.

Our final sample was composed of 433 student participants that provided usable responses. The average age of our sample is 21 years and 44 percent are men. About 10 percent (44 students) do not drink cider, which corresponds to the expected value. The majority of the respondents belong to Generation Z (born after 1996) but a sub-sample of 52 students belong to the Millennials Generation and will be considered as a control group in our analysis. Several recent research reports on alcohol consumption by young people find significant differences due to age (Generation $\mathrm{Z}$ versus Millennials). ${ }^{4}$ A summary of geographical origin of the respondents is shown in Appendix 2. 18 percent of participants are from the two major cider-producing regions in France, which are Bretagne and Normandie. This group will also be considered as a control group in the statistical analyses.

The questionnaire was specifically designed to test whether consumers would pay a premium price or not for quality ciders with respect to a traditional sweet cider with similar characteristics. According to Didier et al. (2012), sweet cider is the most popular type of cider among consumers in France. In our study, it is therefore considered as the baseline product. We are modeling the premium that consumers are willing to pay for an organic cider, a farmer cider and, a rosé cider compared to a sweet cider.

The strategy aims to identify the effects on the difference between WTP for quality ciders (QC) and WTP for a sweet cider (SC).

$\mathrm{WTPi}(\mathrm{k}=\mathrm{QC}-\mathrm{SC})=\alpha+\beta \mathrm{Xi}$

Where $\mathrm{k}$ is the cider dimension (organic, farmer, or rosé).

$\beta$ coefficients measure the respective effects of individual characteristics Xi on WTP.

The most common challenges during the statistical analysis of this model are the deviation from the normal distribution, heteroscedasticity, and error correlations within individuals. The deviation from the normal distrib-

\footnotetext{
3 In most situations a consumer must choose among available options or search for alternatives (Tversky \& Shafir, 1992)). If the situation is known to some extent, ambiguity on the answers is less than expected (Heath \& Tversky, 1991).

4 The mindful low- and no-alcoholic trend, Leasure eNewsletter, Vol. XIX, No. 2, February 2019, White Hutchinson Group, Kansas City, USA.
} 
ution could be due to the small sample size and the presence of some influential observations resulting from participants' erroneous interpretation of questions, unexpected reactions to the conditions of the survey, or some degree of unwillingness to respond seriously. We expect that our research and questionnaire design minimize the impact of these issues.

Deviation from homoskedasticity and statistical independence might be due to unobserved characteristics or unobserved differentiated responses of participants. To deal with this problem and the significant proportion of zero or negative premiums in dependent variables, a two-stage estimation procedure such as Heckman's (1979) sample selection is performed. In order to make the choice model operative, we define the following dependent variables. The discrete nature of the decision "willing to pay a premium price" leads us to use a dichotomous variable, $W T P$, which takes a value of 1 if the consumer is willing to pay a premium price and 0 otherwise. The variable relative to the premium price that the consumer would pay is a quantitative variable that represents the percentage of premium price that the consumer is willing to pay compared to the conventional sweet cider.

Several empirical papers in the consumption literature have found evidence for the role of habits in determining consumption (Constantinides, 1990; Fuhrer \& Klein, 2006; Garcia et al., 1997; Zhen et al., 2011). Familiarity with a product (Alba \& Hutchinson, 1987) and the role of prior experience (Brucks, 1985) are also relevant determinants. Independent variables are related to drinking habits (Question Q1), price habits (Question Q7), cider brand familiarity (Q5: Do you know a brand of cider?), and drinking experience (Q4: In which category do you classify cider?).

Control variables related to age, gender, and behavioral variables are also considered. In this paper, we are dealing with a student population and asking for direct and self-assessment on traits of character, which are likely to be influenced by other personality characteristics, that is, impulsiveness with purchase decisions (Q13) (Bellman, 2012), and optimism (Q14) (Puri \& Robinson, 2007). The use of Likert scales also characterizes the works of Boudreaux \& Palmer (2007) and Orth \& Malkewitz (2008). To keep the questionnaire manageable, the number of self-assessing questions is limited to these major characteristics affecting the purchasing behavior of participants. The table of correlations between the main variables use in this study is shown in Table A2.2 in Appendix 2.

\section{Results \\ 1. Habits and Customs of Respondents}

Table 1 summarizes responses to Questions 1 and 6, which are related to students' drinking habits. Question 1 indicates whether or not students drink cider, and whether they do so regularly. A minority of students drink cider daily (about 12 percent), with a slightly higher percentage for young men than young women drinking cider daily. This percentage increases significantly when measuring the percentage of respondents that drink cider weekly, especially among young men (about 35 percent). Overall, cider is mainly consumed occasionally (about 60 percent of respondents), and this percentage remains the same regardless of respondents' gender. Students buy cider bottles almost exclusively in a supermarket or grocery store (more than 90 percent of respondents). Only 15 percent of respondents may also buy cider occasionally in a liquor store and about 10 percent buy it directly from the producer.

There is no significant difference when we focus on the sub-sample of the Millennials group. However, these results differ to some extent when looking at the region of origin of the students. Indeed, 56 percent of students from producing regions drink cider daily and 67 percent at least twice a week. These figures rise to just over 66 percent and almost 74 percent respectively for men. Thus, our results suggest that drinking habits are significantly shaped by the region of origin of students.

\section{Familiarity with Cider}

Table 2 presents the results relative to students' knowledge and appreciation of the cider market. These results indicate that cider is considered a cheap and non-organic product. Few students know a brand of cider. This drink is classified by all students as an alcoholic beverage but not in the same manner as wine. Cider is rather classified in the same category as beer. Male students from producing regions consider that it is possible to drink cider during a meal the same way beer is used in the Northern and Eastern regions. Cider may also be classified as soda because of the sweetness of the beverage and this result is significantly higher for the Millennials group.

Cider is more festive for women than for men. As expected, it is also a beverage associated with specific circumstances like Epiphany cake, King Cake, crepes, and dessert (Didier et al., 2012). This status is true whatever the students' region of origin. On the other hand, students do not consider cider as a beverage for events such as the aperitif or a wedding. Happy hours and student evenings might be a good time to drink cider for about half of the students. There is no significant difference among generations of consumers.

\section{The Willingness to Pay for Quality Cider}

The average price paid for a bottle of cider (Q7) when invited to a friend's place (price habit) is 4.23 EUR (about 5.0 USD) and varies from 2 EUR to 8 EUR (between 2.4 and 9.5 USD). This price is almost identical when students are drinking cider outside (Q8). These results are also identical regardless of respondent's gender and region of origin. This low price is in line with the students' opinion of cider as a cheap beverage (Q2).

The average price paid for a bottle of sweet cider (Q9) is about 5.0 USD and is almost identical to the price habit de-

5 Detailed results by sub-sample groups are available from the authors upon request. 
Table 1. Percentage of Affirmative Answers Regarding Drinking Habits and Purchasing Location

\begin{tabular}{|c|c|c|c|c|c|c|}
\hline & Men & Women & Total & $\begin{array}{l}\text { Men from } \\
\text { producing } \\
\text { regions }\end{array}$ & $\begin{array}{l}\text { Women from } \\
\text { producing regions }\end{array}$ & $\begin{array}{l}\text { All respondents from } \\
\text { producing regions }\end{array}$ \\
\hline \multicolumn{7}{|l|}{ Drinking Habits } \\
\hline Q1a Daily & $14 \%$ & $10 \%$ & $12 \%$ & $66 \%$ & $48 \%$ & $56 \%$ \\
\hline Q1b Weekly & $35 \%$ & $28 \%$ & $30 \%$ & $74 \%$ & $61 \%$ & $67 \%$ \\
\hline $\begin{array}{l}\text { Q1c } \\
\text { Occasionally }\end{array}$ & $58 \%$ & $60 \%$ & $58 \%$ & $26 \%$ & $37 \%$ & $32 \%$ \\
\hline \multicolumn{7}{|c|}{ Purchase Location } \\
\hline $\begin{array}{l}\text { Q6a Liquor } \\
\text { store }\end{array}$ & $16 \%$ & $14 \%$ & $15 \%$ & $20 \%$ & $13 \%$ & $16 \%$ \\
\hline $\begin{array}{l}\text { Q6b } \\
\text { Supermarket }\end{array}$ & $90 \%$ & $93 \%$ & $92 \%$ & $89 \%$ & $96 \%$ & $93 \%$ \\
\hline $\begin{array}{l}\text { Q6c } \\
\text { Producer }\end{array}$ & $6 \%$ & $10 \%$ & $9 \%$ & $34 \%$ & $46 \%$ & $41 \%$ \\
\hline
\end{tabular}

Table 3. Values for WTP (Means and Standard Deviations)

\begin{tabular}{lcc}
\hline & Average Willingness to Pay & Premium (QC-SC) \\
\hline Organic cider & $€ 5.72(0.77)$ & $€ 1.51(1.28)$ \\
Farmer cider & $€ 6.01(0.99)$ & $€ 1.84(1.37)$ \\
Rosé cider & $€ 6.02(0.89)$ & $€ 1.84(1.38)$ \\
\hline
\end{tabular}

$\mathrm{QC}=$ Quality Cider $; \mathrm{SC}=$ Sweet Cider. Values are in $€$ Euros.

termined in Q7. More than 87 percent of the participants are willing to pay a premium for a quality cider compared to the price they are willing to pay for a traditional sweet cider. Table 3 shows the average price that respondents are willing to pay (WTP) for organic, farmer, and rosé ciders and the premium paid compared to the standard sweet cider.

In the analyses shown on Table 4 below, the dependent variable (i.e., the willingness to pay a premium or not), is a binary variable and the coefficients are probit estimates. Out of 433 respondents in our sample, 54 participants (13 percent) are not willing to pay a premium for a quality cider compared to the traditional sweet cider. Age and gender are the most significant variables affecting the willingness to pay a premium. Participants associating cider to beer (Q4) are willing to pay a positive premium, although this difference is not statistically significant. By contrast, the association of cider to soda implies a negative effect. Similarly, participants drinking cider occasionally (Q1) may be willing to pay a premium (not statistically significant) and by contrast, daily drinkers are not willing to pay any premium. Participants who claim to have some knowledge of the cider market (Q5) (Knowledge $=1$ if they know more than one brand, 0 otherwise) are willing to pay a significant premium for a quality cider. Participants who claim that cider directly from the producer (Q6) are not willing to pay a premium but the negative sign is not statistically significant. Finally, the behavioral variables (Q13) are never significant in any of the models.

In the Heckman selection model, age is the most significant selection variable. In a second step, the variable relative to the premium that the consumer would pay is a quantitative variable that represents the percentage of premium price that the consumer is willing to pay for a quality cider compared to the conventional sweet cider. The discrete nature of the decision "willing to pay a premium price" leads us to estimate the response equation through the Heckman procedure. The same variables are considered to estimate the dependent variables and the price habit variable (Q7) is added to the model since the premium to be paid is normally relative to the price habit of consumers, i.e., the more they usually pay for a bottle of cider, the more likely they already prefer a quality cider and the less likely they would be willing to pay a high premium. Therefore, it is expected that the price habit is negatively related to the premium. 
Table 2. Percentage of Affirmative Answers Regarding Respondents' Preferences

\begin{tabular}{|c|c|c|c|c|c|c|}
\hline & Men & Women & Total & $\begin{array}{l}\text { Men from } \\
\text { producing } \\
\text { regions }\end{array}$ & $\begin{array}{l}\text { Women from } \\
\text { producing } \\
\text { regions }\end{array}$ & $\begin{array}{l}\text { All respondents } \\
\text { from producing } \\
\text { regions }\end{array}$ \\
\hline \multicolumn{7}{|c|}{ Words to Describe Cider } \\
\hline Q2a Organic & $19 \%$ & $20 \%$ & $20 \%$ & $11 \%$ & $13 \%$ & $12 \%$ \\
\hline Q2b Festive & $42 \%$ & $60 \%$ & $52 \%$ & $31 \%$ & $50 \%$ & $41 \%$ \\
\hline Q2c Rustic & $42 \%$ & $51 \%$ & $47 \%$ & $31 \%$ & $41 \%$ & $37 \%$ \\
\hline $\begin{array}{l}\text { Q2d Old- } \\
\text { fashioned }\end{array}$ & $46 \%$ & $53 \%$ & $50 \%$ & $39 \%$ & $48 \%$ & $44 \%$ \\
\hline Q2e Sweet & $76 \%$ & $71 \%$ & $73 \%$ & $78 \%$ & $70 \%$ & $73 \%$ \\
\hline Q2f Natural & $43 \%$ & $45 \%$ & $44 \%$ & $33 \%$ & $50 \%$ & $43 \%$ \\
\hline Q2g Familial & $43 \%$ & $45 \%$ & $44 \%$ & $33 \%$ & $48 \%$ & $41 \%$ \\
\hline Q2h Cheap & $74 \%$ & $73 \%$ & $73 \%$ & $69 \%$ & $76 \%$ & $73 \%$ \\
\hline Q2i Quickly drunk & $16 \%$ & $15 \%$ & $15 \%$ & $17 \%$ & $17 \%$ & $17 \%$ \\
\hline Q2j Apple & $76 \%$ & $80 \%$ & $79 \%$ & $81 \%$ & $83 \%$ & $82 \%$ \\
\hline Q2k Soil & $52 \%$ & $47 \%$ & $49 \%$ & $44 \%$ & $43 \%$ & $44 \%$ \\
\hline \multicolumn{7}{|c|}{ Events Associated with Cider } \\
\hline Q3a Birthday & $34 \%$ & $34 \%$ & $34 \%$ & $39 \%$ & $26 \%$ & $32 \%$ \\
\hline Q3b King cake & $92 \%$ & $92 \%$ & $92 \%$ & $92 \%$ & $98 \%$ & $95 \%$ \\
\hline Q3c Wedding & $22 \%$ & $22 \%$ & $22 \%$ & $22 \%$ & $22 \%$ & $22 \%$ \\
\hline $\begin{array}{l}\text { Q3d Epiphany } \\
\text { cake }\end{array}$ & $94 \%$ & $93 \%$ & $94 \%$ & $97 \%$ & $93 \%$ & $95 \%$ \\
\hline Q3e Crepes & $99 \%$ & $100 \%$ & $99 \%$ & $100 \%$ & $100 \%$ & $100 \%$ \\
\hline Q3f Dessert & $79 \%$ & $64 \%$ & $71 \%$ & $83 \%$ & $63 \%$ & $72 \%$ \\
\hline Q3g Aperitif & $28 \%$ & $17 \%$ & $22 \%$ & $28 \%$ & $17 \%$ & $22 \%$ \\
\hline Q3h Main course & $43 \%$ & $14 \%$ & $27 \%$ & $69 \%$ & $13 \%$ & $38 \%$ \\
\hline Q3i Happy hour & $57 \%$ & $36 \%$ & $45 \%$ & $47 \%$ & $43 \%$ & $45 \%$ \\
\hline $\begin{array}{l}\text { Q3j Student } \\
\text { evening }\end{array}$ & $52 \%$ & $52 \%$ & $52 \%$ & $53 \%$ & $54 \%$ & $54 \%$ \\
\hline Q3k Buffet diner & $40 \%$ & $40 \%$ & $40 \%$ & $39 \%$ & $43 \%$ & $41 \%$ \\
\hline \multicolumn{7}{|c|}{ Categorization of Cider } \\
\hline $\begin{array}{l}\text { Q4a Alcoholic } \\
\text { drink }\end{array}$ & $99 \%$ & $99 \%$ & $99 \%$ & $100 \%$ & $98 \%$ & $99 \%$ \\
\hline Q4b Beer & $61 \%$ & $36 \%$ & $47 \%$ & $72 \%$ & $41 \%$ & $55 \%$ \\
\hline Q4c Soda & $48 \%$ & $44 \%$ & $46 \%$ & $56 \%$ & $52 \%$ & $54 \%$ \\
\hline Q4d Wine & $3 \%$ & $1 \%$ & $2 \%$ & $8 \%$ & $0 \%$ & $4 \%$ \\
\hline
\end{tabular}

Table 4. Predictors of the Willingness to Pay a Premium

\begin{tabular}{|c|c|c|c|c|}
\hline Variable & Coef. & S.E. & $z$-value & \\
\hline Age & 0.04 & 0.01 & 5.87 & $* * *$ \\
\hline Gender & 0.25 & 0.16 & 1.55 & ** \\
\hline Associates cider with beer & 0.20 & 0.17 & 1.19 & \\
\hline Occasional drinker & 0.08 & 0.16 & 0.52 & \\
\hline Knowledge of cider & 0.46 & 0.32 & 1.43 & $*$ \\
\hline Buys from producer & -0.34 & 0.29 & -1.17 & \\
\hline S.E. of regression & 0.33 & & & \\
\hline
\end{tabular}

Note: **** Significant at 5 percent; ** Significant at 10 percent; * Significant at 15 percent; S.E. $=$ Standard Error 
Table 5. The Willingness to Pay a Premium

\begin{tabular}{|c|c|c|c|c|c|c|c|c|c|c|c|c|}
\hline & \multicolumn{4}{|c|}{ Premium for Organic Cider } & \multicolumn{4}{|c|}{ Premium for Farmer Cider } & \multicolumn{4}{|c|}{ Premium for Rosé Cider } \\
\hline & Coef. & S.E. & $t$-value & & Coef. & S.E. & $\mathrm{t}$-value & & Coef. & S.E. & t-value & \\
\hline Age & 0.00 & 0.01 & 0.47 & & 0.00 & 0.01 & 0.04 & & 0.01 & 0.01 & 0.92 & \\
\hline Gender & 0.14 & 0.08 & 1.67 & $* *$ & 0.20 & 0.10 & 2.01 & $* * *$ & 0.12 & 0.08 & 1.39 & $*$ \\
\hline Associates cider with beer & 0.09 & 0.08 & 1.20 & & 0.10 & 0.09 & 1.12 & & 0.10 & 0.08 & 1.20 & \\
\hline Drinks occasionally & 0.01 & 0.04 & 0.14 & & 0.06 & 0.05 & 1.32 & * & 0.03 & 0.04 & 0.98 & \\
\hline Knowledge of cider & 0.22 & 0.28 & 0.78 & & 0.29 & 0.33 & 0.89 & & 0.25 & 0.28 & 0.90 & \\
\hline Buys from producer & -0.14 & 0.11 & -1.24 & & -0.29 & 0.13 & -2.25 & $* * *$ & -0.34 & 0.11 & -3.06 & *** \\
\hline Price habit & -0.03 & 0.02 & -1.92 & $* * *$ & -0.03 & 0.02 & -1.44 & $*$ & -0.04 & 0.02 & -2.03 & *** \\
\hline Inverse Mills ratio & 1.82 & 0.66 & 2.77 & $* * *$ & 2.21 & 0.78 & 2.84 & $* * *$ & 1.85 & 0.67 & 2.77 & *** \\
\hline Sigma & 1.08 & & & & 1.31 & & & & 1.10 & & & \\
\hline Rho & 1.68 & & & & 1.69 & & & & 1.68 & & & \\
\hline
\end{tabular}

Note: **** Significant at 5 percent; *** Significant at 10 percent; * Significant at 15 percent. 
The results of the analyses of the predictors of respondents' willingness to pay a premium price for organic cider, farmer cider, and rosé cider are presented in Table 5 . As expected, the Inverse Mills ratio is positive and statistically significant, which means there is a positive selection due to age and implies that its inclusion is necessary to avoid a missing variable or sample truncation bias. Therefore, the willingness to pay a premium for a quality cider in the Heckman procedure is no more related to age but still significantly related to gender for the three types of cider, i.e., organic, farmer, and rosé.

Results also show significant differences among the three types of ciders. Participants drinking cider occasionally may be willing to pay a significant premium but only for farmer cider. Participants who claim to buy cider directly from the producer (Q6) are not willing to pay a premium and the negative sign is only statistically significant for farmer and rosé ciders. It is, therefore, more likely that consumers buy these types of ciders in liquor stores or supermarkets contrary to organic ciders.

As expected, the habit formation hypothesis is validated. The price habit variable is negative and significant for the three types of cider. The drinking habit variable is positive and significantly impacting the decision to pay for a quality cider like a farmer cider but not an organic cider. This result is in line with the survey preferences showing that cider is not associated with an organic product. Cider brand familiarity (Q5) and association with beer have the expected positive sign but no statistically significant impact on the willingness to pay a premium.

\section{Discussion}

Our study provides important insights regarding cider perception and consumption among young consumers. First, cider has an image of a cheap product, made from apple but not organic. Females consider it more festive than males. Young consumers are mostly unfamiliar with cider brands. Cider is associated with special events (i.e. epiphany, King Cake, crepes) and classified in the same category as beer or, to a lesser extent, soda. Students from producing regions prefer buying directly from a producer while other students favor supermarkets or grocery stores. However, the distribution channel has no significant effect on young consumers' preferences.

Second, all study participants were willing to pay approximately the same average price for a bottle of cider at a friend's place or outside. Participants were also willing to pay almost 50 percent more for specific quality products like rosé, farmer, and organic ciders. This is consistent with the findings of Hall et al.'s (2004) study of young adult wine consumers, and is also consistent with results of studies about wine consumers in general (Quester \& Smart, 1998).

\subsection{Theoretical Implications}

Our study not only expands our knowledge about the consumption of cider but also enhances our understanding about general attitudes and perceptions of young people towards moderate alcohol consumption. By comparison, Silva et al. (2014) show that special occasions and parties with friends are the main occasions for wine consumption, where the motivation is to facilitate socialization and fun.

Our empirical analysis demonstrates the role of habit formation on the purchasing decision-making process for alcoholic beverages. We find that price habit significantly predicts WTP and cider brand familiarity, although the effect of drinking experience on the willingness to pay a positive premium is not statistically significant. The frequency of drinking habits positively and significantly predicts the decision to pay for a better-quality cider such as a farmer cider.

\subsection{Managerial Implications}

There are interesting practical and managerial implications from our survey and empirical results. Since young adults will potentially be the next generation of consumers of other alcoholic beverages, it can be beneficial for marketers to focus on this target population. Several insights from our study are relevant for industry managers and executives. First, our results suggest that brands are unknown. This indicates that advertising a brand or a name could facilitate the identity of the beverage and its association to special circumstances. Second, cider is associated with beer or soda. Focusing on the natural aspect of the beverage in comparison with other competitive products should be considered. Third, sweetness is often associated with cider. There is a positive incentive to pay a higher premium for a cider rosé. In the same way, cider rosé is attractive, flavored ciders with new aromas and colors (e.g. vanilla, cherry, red fruits, passion fruits, or exotic fruits) would very likely be successful products. Our research study might also be useful as a starting point for further studies comparing alternative or competitive beverages.

\subsection{Limitations/Directions for Future Research}

The inherent limitations of data collection must be considered. The methodology employed and the small sample size, mean that the results cannot be validly generalized from this sample of students to the demographic of young alcohol consumers as a whole. Focusing on a specific group of students, however, permits the gathering of relevant qualitative data for an exploratory study. Since the participants are a market segment that represents current and potential future consumers, companies in the beverage industry including the wine industry should be aware of the attitudes, perceptions, preferences, and behavior of this age group in order to adapt to their current and future needs and expectations. It should also be kept in mind that consumers' self-reported purchase intentions do not perfectly predict their future purchase behavior (Chandon et al., 2005).

Future research could focus on the reasons for why students are willing to pay a premium for fun drinks like the co-ferment of beer and blueberry juice that taste like a Lambrusco or rosé crispy ciders with flavors of pears that taste like a Prosecco. As documented in Fabien-Ouellet \& Conner (2018), this is a promising area for future research. The increasing hybridization of wine, beer, and cider makes each beverage become increasingly blurred and redefines the areas of competition between products and markets. 


\section{Conclusion}

In this paper, we consider the WTP approach to understanding whether habits and purchasing behavior of the younger generation impact the willingness to pay for one bottle of cider. A questionnaire was distributed to French business students from December 2017 to January 2018 at INSEEC Bordeaux Business School. A large majority of the participants are willing to pay a premium for a quality cider compared to the traditional sweet cider. The empirical analysis shows that the willingness to pay a premium for a quality product is mainly determined by gender differences and habit formation, including habitual prices and drinking habits.

\section{Acknowledgement}

The authors appreciate the useful comments received from the editor and reviewers. 


\section{Questionnaire (English translation of the original French questionnaire)}

Your answers are declarative and measure your preference. Therefore, there is no good or wrong answer. Just tick or encircle your answer.

Question 1. Do you drink cider?
a. Daily
b. A few times a week (but not daily)
c. Occasionally
Yes $\quad$ No
Yes No

uestion 2. Which of the following words are relevant to cider?

$\begin{array}{lll}\text { a. Organic } & \text { Yes } & \text { No } \\ \text { b. Festive } & \text { Yes } & \text { No } \\ \text { c. Rustic } & \text { Yes } & \text { No } \\ \text { d. Old-fashioned } & \text { Yes } & \text { No } \\ \text { e. Sweet } & \text { Yes } & \text { No } \\ \text { f. Natural } & \text { Yes } & \text { No } \\ \text { g. Familial } & \text { Yes } & \text { No } \\ \text { h. Cheap } & \text { Yes } & \text { No } \\ \text { i. Quickly drunk } & \text { Yes } & \text { No } \\ \text { j. Apple } & \text { Yes } & \text { No } \\ \text { k. Soil } & \text { Yes } & \text { No }\end{array}$

Question 3. What events and meals can cider be linked to?

$\begin{array}{lll}\text { a. Birthday } & \text { Yes } & \text { No } \\ \text { b. King Cake } & \text { Yes } & \text { No } \\ \text { c. Wedding } & \text { Yes } & \text { No } \\ \text { d. Epiphany cake } & \text { Yes } & \text { No } \\ \text { e. Crepes } & \text { Yes } & \text { No } \\ \text { f. Dessert } & \text { Yes } & \text { No } \\ \text { g. Aperitif } & \text { Yes } & \text { No } \\ \text { h. Main course } & \text { Yes } & \text { No } \\ \text { i. Happy hours } & \text { Yes } & \text { No } \\ \text { j. Student evening } & \text { Yes } & \text { No } \\ \text { k. Buffet dinner } & \text { Yes } & \text { No }\end{array}$

Question 4. In which category do you classify cider?

$\begin{array}{lll}\text { a. Alcoholic drink } & \text { Yes } & \text { No } \\ \text { b. Beer } & \text { Yes } & \text { No } \\ \text { c. Soda } & \text { Yes } & \text { No } \\ \text { d. Wine } & \text { Yes } & \text { No }\end{array}$

Question 5. Do you know a brand of cider?

If Yes, more than 1 ?

$\begin{array}{ll}\text { Yes } & \text { No } \\ \text { Yes } & \text { No }\end{array}$

Question 6. Where do you buy cider?
a. Liquor store
b. Supermarket
c. Farm or producer

$\begin{array}{ll}\text { Yes } & \text { No } \\ \text { Yes } & \text { No } \\ \text { Yes } & \text { No }\end{array}$

Question 7. How much do you spend on average for a bottle of cider that you offer when you are invited to a friend's party?

Question 8. How much do you spend on average for a bottle of cider when you are at a restaurant or creperie?

Question 9. How much are you willing to pay for sweet cider?

Question 10. How much are you willing to pay for organic cider?

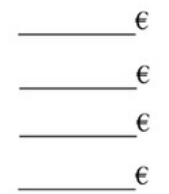

Question 11. How much are you willing to pay for rosé cider?

Question 12. How much are you willing to pay for farmer cider? $€$

Question 13:

a. On a scale from 1 (rather price-oriented) to 5 (rather spender) where do you position yourself in comparison with the average population:

b. On a scale from 1 (rather optimist) to 5 (rather pessimist) where do you position yourself in comparison with the average population:

Question 14: Although this questionnaire is confidential, we would like to know some information in order to treat the answers. Thanks in advance for your understanding.

Gender: Man Woman

Age: 


\section{APPENDIX 2}

Table A2.1. Characteristics of the Sample of Respondents

\begin{tabular}{|c|c|c|c|c|c|c|c|c|c|c|c|c|c|}
\hline \multicolumn{14}{|c|}{ Male } \\
\hline Total & 19 years old & 20 years old & 21 years old & 22 years old & 23 years old & 24 years old & 25 years old & Auvergne & Bretagne & Normandie & Nlle Aquitaine & Occitanie & Pays-de-Loire \\
\hline $\begin{array}{l}190 \\
44 \%\end{array}$ & $\begin{array}{l}11 \\
41 \%\end{array}$ & $\begin{array}{l}30 \\
38 \%\end{array}$ & $\begin{array}{l}100 \\
48 \%\end{array}$ & $\begin{array}{l}25 \\
37 \%\end{array}$ & $\begin{array}{l}14 \\
38 \%\end{array}$ & $\begin{array}{l}6 \\
60 \%\end{array}$ & $\begin{array}{l}4 \\
80 \%\end{array}$ & $\begin{array}{l}1 \\
50 \%\end{array}$ & $\begin{array}{l}29 \\
43 \%\end{array}$ & $\begin{array}{l}7 \\
64 \%\end{array}$ & $\begin{array}{l}137 \\
44 \%\end{array}$ & $\begin{array}{l}14 \\
38 \%\end{array}$ & $\begin{array}{l}2 \\
40 \%\end{array}$ \\
\hline \multicolumn{14}{|c|}{ Female } \\
\hline Total & 19 years old & 20 years old & 21 years old & 22 years old & 23 years old & 24 years old & 25 years old & Auvergne & Bretagne & Normandie & Nlle Aquitaine & Occitanie & Pays-de-Loire \\
\hline $\begin{array}{l}243 \\
56 \%\end{array}$ & $\begin{array}{l}16 \\
59 \%\end{array}$ & $\begin{array}{l}48 \\
62 \%\end{array}$ & $\begin{array}{l}108 \\
52 \%\end{array}$ & $\begin{array}{l}43 \\
63 \%\end{array}$ & $\begin{array}{l}23 \\
62 \%\end{array}$ & $\begin{array}{l}4 \\
40 \%\end{array}$ & $\begin{array}{l}1 \\
20 \%\end{array}$ & $\begin{array}{l}1 \\
50 \%\end{array}$ & $\begin{array}{l}39 \\
57 \%\end{array}$ & $\begin{array}{l}4 \\
36 \%\end{array}$ & $\begin{array}{l}173 \\
56 \%\end{array}$ & $\begin{array}{l}23 \\
62 \%\end{array}$ & $\begin{array}{l}3 \\
60 \%\end{array}$ \\
\hline \multicolumn{14}{|c|}{ Total } \\
\hline Total & 19 years old & 20 years old & 21 years old & 22 years old & 23 years old & 24 years old & 25 years old & Auvergne & Bretagne & Normandie & Nlle Aquitaine & Occitanie & Pays-de-Loire \\
\hline 433 & 27 & 78 & 208 & 68 & 37 & 10 & 5 & 2 & 68 & 11 & 310 & 37 & 5 \\
\hline
\end{tabular}


Table A2.2. Table of Correlations between Variables

\begin{tabular}{|c|c|c|c|c|c|c|}
\hline & (1) & (2) & (3) & (4) & (5) & (6) \\
\hline \multicolumn{7}{|l|}{ (1) Age } \\
\hline (2) Gender & 0.45 & & & & & \\
\hline (3) Associates cider to beer & 0.57 & 0.61 & & & & \\
\hline (4) Occasional drinker & 0.32 & -0.10 & 0.21 & & & \\
\hline (5) Knowledge of cider & 0.67 & 0.15 & 0.45 & 0.21 & & \\
\hline (6) Buys from producer & 0.13 & 0.31 & -0.06 & 0.45 & 0.17 & \\
\hline
\end{tabular}

Submitted: April 30, 2021 PDT, Accepted: August 23, 2021 PDT 


\section{References}

Adaval, R., \& Monroe, K. B. (2002). Automatic construction and use of contextual information for product and price evaluations. Journal of Consumer Research, 28(4), 572-588. https://doi.org/10.1086/338 $\underline{212}$

AICV. (2018). European cider trends. European Cider and Fruit Wine Association, Brussels. http://www.aicv.or g/pages/aicv/publications.html

Alba, J. W., \& Hutchinson, J. W. (1987). Dimensions of consumer expertise. Journal of Consumer Research, 13(4), 411-454. https://doi.org/10.1086/209080

Arvers, P. (2011). Age de début de consommation d'alcool: Evolution dans le temps (1993-2007) chez les adolescents et rôle dans les alcoolisations massives. Analyse réalisée à partir des données INSERM (1993) et ESPAD (1999-2003-2007). Cahiers de l'Ireb, 20, 111-116.

Barber, N. A., \& Taylor, D. C. (2013). Experimental approach to assessing actual wine purchase behavior. International Journal of Wine Business Research, 25(3), 203-226. https://doi.org/10.1108/ijwbr-2012-0013

Barber, N., Almanza, B. A., \& Donovan, J. (2006). Motivational factors of gender, income and age on selecting a bottle of wine. International Journal of Wine Business Research, 18(3), 218-232.

Bearden, W. O., Kaicker, A., Borrero, M., \& Urbany, J. E. (1992). Examining alternative operational measures of internal reference prices. In J. F. Jr. Sherry \& B. Sternthal (Eds.), Advances in Consumer Research (Vol. 19, pp. 629-635). Association for Consumer Research.

Bellman, S. B. (2012). I would rather be happy than right: Consumer impulsivity, risky decision making, and accountability. Doctoral Dissertation, University of Iowa.

Boudreaux, C. A., \& Palmer, S. E. (2007). A charming little cabernet: Effects of wine label design on purchase intent and brand personality. International Journal of Wine Business Research, 19(3), 170-186. htt ps://doi.org/10.1108/17511060710817212

Brucks, M. (1985). The effects of product class knowledge on information search behavior. Journal of Consumer Research, 12(1), 1-16. https://doi.org/10.10 $\underline{86 / 209031}$

Brugarolas Mollá-Bauzá, M. M., Martínez-Carrasco, L., Martínez-Poveda, A., \& Rico Pérez, M. (2005). Determination of the surplus that consumers are willing to pay for an organic wine. Spanish Journal of Agricultural Research, 3(1), 43. https://doi.org/10.542 4/sjar/2005031-123

Capehart, K. W. (2015). Fine water: A hedonic pricing approach. Journal of Wine Economics, 10(2), 129-150. https://doi.org/10.1017/jwe.2015.15

Cardebat, J.-M., \& Figuet, J.-M. (2004). What explains Bordeaux wine prices? Applied Economics Letters, 11(5), 293-296. https://doi.org/10.1080/13504850420 00221544
Chandon, P., Morwitz, V. G., \& Reinartz, W. J. (2005). Do intentions really predict behavior? Self-generated validity effects in survey research. Journal of Marketing, 69(2), 1-14. https://doi.org/10.1509/jmk g.69.2.1.60755

Charters, S., \& Pettigrew, S. (2008). Why do people drink wine? A consumer-focused exploration. Journal of Food Products Marketing, 14(3), 13-32. https://doi.o $\mathrm{rg} / 10.1080 / 10454440801985894$

Cloutier, E. M., \& Détolle, A. (2017). La transformation du cidre au Québec: Perspective écosystémique. Presses Universitaires du Québec, Montréal, Canada.

Constantinides, G. M. (1990). Habit formation: A resolution of the equity premium puzzle. Journal of Political Economy, 98(3), 519-543. https://doi.org/10.1 $\underline{086 / 261693}$

Craigs, C. L., Bewick, B. M., Gill, J., O’May, F., \& Radley, D. (2011). UK student alcohol consumption: A cluster analysis of drinking behaviour typologies. Health Education Journal, 71(4), 516-526. https://doi.org/1 $\underline{0.1177 / 0017896911406967}$

Didier, A., Symoneaux, R., Schlich, P., Sybiril, S., Droger, D., Baudin, R., \& Raimbaud, F. J. (2012). Le cidre, d'une logique de l'offre vers une démarche marketing de la demande. Innovations Agronomiques, 25, 1-14.

Fabien-Ouellet, N., \& Conner, D. S. (2018). The identity crisis of hard cider. Journal of Food Research, 7(2), 654-676. https://doi.org/10.5539/jfr.v7n2p54

FAGE. (2014). Enquête sur les habitudes de consommation d'alcool des étudiants et leurs rapports aux actions de prévention. Fédération des Associations Générales d'Etudiants, Dempsey Senez, Hauts-de-France.

Fogarty, J. J. (2010). The demand for beer, wine and spirits: A survey of the literature. Journal of Economic Surveys, 24(3), 428-478.

Foster, S. E., Vaughan, R. D., Foster, W. H., \& Califano, J. A. (2003). Alcohol consumption and expenditures for underage drinking and adult excessive drinking. JAMA, 289(8), 989-995. https://doi.org/10.1001/jam a.289.8.989

Fuhrer, J. C., \& Klein, M. W. (2006). Risky Habits: On Risk Sharing, Habit Formation, and the Interpretation of International Consumption Correlations. Review of International Economics, 14(4), 722-740. https://doi.o $\mathrm{rg} / 10.1111 / \mathrm{j} .1467-9396.2006 .00616 . \mathrm{X}$

Garcia, R., Lusardi, A., \& Ng, S. (1997). Excess sensitivity and asymmetries in consumption: An empirical investigation. Journal of Money, Credit and Banking, 29(2), 154. https://doi.org/10.2307/2953673

Heath, C., \& Tversky, A. (1991). Preference and belief: Ambiguity and competence in choice under uncertainty. Journal of Risk and Uncertainty, 4(1), 5-28. https://doi.org/10.1007/bf00057884

Heckman, J. J. (1979). Sample selection bias as a specification error. Econometrica, 47(1), 153-161. http s://doi.org/10.2307/1912352 
Hicks, J., Waltz, M., \& Riedy, C. (2018). Crossgenerational counseling strategies: Understanding unique needs of each generation. Journal of Counselor Practice, 9(1), 6-23.

Holmquist, C., McCluskey, J., \& Ross, C. (2011). Consumer preferences and willingness to pay for oak attributes in Washington chardonnays. American Journal of Agricultural Economics, 94(2), 556-561. http s://doi.org/10.1093/ajae/aar071

Ji, M. F., \& Wood, W. (2007). Purchase and consumption habits: Not necessarily what you intend. Journal of Consumer Psychology, 17(4), 261-276. https://doi.org/ 10.1016/s1057-7408(07)70037-2

Kalyanaram, G., \& Little, J. D. C. (1994). An empirical analysis of latitude of price acceptance in consumer package goods. Journal of Consumer Research, 21(3), 408-418. https://doi.org/10.1086/209407

Lecat, B., Le Fur, E., \& Outreville, J. F. (2016). Perceived risk and the willingness to buy and pay for "corked" bottles of wine. International Journal of Wine Business Research, 28(4), 286-307. https://doi.org/10.1108/ijwb r-08-2015-0031

Lecocq, S., \& Visser, M. (2006). What determines wine prices: Objective vs. sensory characteristics. Journal of Wine Economics, 1(1), 42-56. https://doi.org/10.1017/ s1931436100000080

Lockshin, L., \& Hall, J. (2003). Consumer purchasing behaviour for wine: What we know and where we are going. Proceedings of the International Wine Marketing Colloquium, Adelaide, Australia.

Nelson Barber, N. (2009). Wine consumers' environmental knowledge and attitudes: Influence on willingness to purchase. International Journal of Wine Research, 1, 59-72. https://doi.org/10.2147/ijwr.s4649

Oczkowski, E., \& Doucouliagos, H. (2015). Wine Prices and Quality Ratings: A Meta-regression Analysis. American Journal of Agricultural Economics, 97(1), 103-121. https://doi.org/10.1093/ajae/aau057

Olsen, J. E., Thach And, L., \& Nowak, L. (2007). Wine for my generation: Exploring how US wine consumers are socialized to wine. Journal of Wine Research, 18(1), 1-18. https://doi.org/10.1080/09571260701526816

Orth, U. R., \& Kahle, L. R. (2008). Intrapersonal variation in consumer susceptibility to normative influence: Toward a better understanding of brand choice decisions. The Journal of Social Psychology, 148(4), 423-448. https://doi.org/10.3200/socp.148.4.4 23-448

Orth, U. R., \& Malkewitz, K. (2008). Holistic package design and consumer brand impressions. Journal of Marketing, 72(3), 64-81. https://doi.org/10.1509/jmk g.72.3.064

Outreville, J. F., \& Le Fur, E. (2020). The price of cider: Empirical analysis in Québec Province. British Food Journal, 122(1), 87-98. https://doi.org/10.1108/bfj-0 7-2019-0561

Outreville, J.-F., \& Le Fur, E. (2020). Hedonic price functions and wine price determinants: A review of empirical research. Journal of Agricultural \& Food Industrial Organization, 18(2), 1-27. https://doi.org/1 $\underline{0.1515 / \text { iafio-2019-0028 }}$
Pepper, K. (2018). Next up: Think Millennials are tricky bunch? Meet Generation Z. Beverage Journal, 80(2), 34-39.

Pollak, R. A. (1970). Habit formation and dynamic demand functions. Journal of Political Economy, 78(4), 745-763. https://doi.org/10.1086/259667

Pollak, R. A. (1976). Interdependent preferences. American Economic Review, 66(3), 309-320.

Puri, M., \& Robinson, D. (2007). Optimism and economic choice ts. Journal of Financial Economics, 86(1), 71-99. https://doi.org/10.1016/i.jfineco.2006.0 9.003

Richard, J. B., Beck, F., \& Spilka, S. (2013). La consommation d'alcool des 18-25 ans en 2010 en France: Spécificités et évolutions depuis 2005. Bulletin d'Epidémiologie Hebdomadaire, 16-17-18, 176-179.

Rouillier, P., Boutron-Ruault, M.-C., Bertrais, S., Arnault, N., Daudin, J.-J., Bacro, J.-N., \& Hercberg, S. (2004). Drinking patterns in French adult men: A cluster analysis of alcoholic beverages and relationship with lifestyle. European Journal of Nutrition, 43(2), 69-76. https://doi.org/10.1007/s0039 4-004-0442-X

Sellers-Rubio, R., \& Nicolau-Gonzalbez, J. L. (2016). Estimating the willingness to pay for a sustainable wine using a Heckit model. Wine Economics and Policy, 5(2), 96-104. https://doi.org/10.1016/j.wep.201 $\underline{6.09 .002}$

Silva, A. P., Figueiredo, I., Hogg, T., \& Sottomayor, M. (2014). Young adults and wine consumption a qualitative application of the theory of planned behavior. British Food Journal, 116(5), 832-848. http s://doi.org/10.1108/bfj-05-2012-0114

Sousa, J. (2014). Estimation of price elasticities of demand for alcohol in the United Kingdom (HMRC Working Paper 16).

Thach, E. C., \& Olsen, J. E. (2006). Market segment analysis to target young adult wine drinkers. Agribusiness, 22(3), 307-322. https://doi.org/10.1002/ agr.20088

Tozer, P. R., Galinato, S. P., Ross, C. F., Miles, C. A., \& McCluskey, J. J. (2015). Sensory analysis and willingness to pay for craft cider. Journal of Wine Economics, 10(3), 314-328. https://doi.org/10.1017/jw e.2015.30

Tversky, A., \& Shafir, E. (1992). Choice under conflict: The dynamics of deferred decision. Psychological Science, 3(6), 358-361. https://doi.org/10.1111/j.146 7-9280.1992.tb00047.x

Watson, B. (2003). Cider, hard and sweet: History, traditions and making your own. Countryman Press: Woodstock, VT.

Yang, N., McCluskey, J. J., \& Ross, C. (2009). Willingness to pay for sensory properties in Washington State red wines. Journal of Wine Economics, 4(1), 81-93. http s://doi.org/10.1017/s1931436100000699

Zhen, C., Wohlgenant, M. K., Karns, S., \& Kaufman, P. (2011). Habit Formation and Demand for Sugar-Sweetened Beverages. American Journal of Agricultural Economics, 93(1), 175-193. https://doi.or $\mathrm{g} / 10.1093 /$ ajae/aaq155 